\title{
The evaluation model of public buildings' management efficiency with emphasis on social aspect
}

\author{
Jūratė Šliogerienè, Tatjana Vilutiené* \\ Department of Construction Construction Management and Real Estate, \\ Vilnius Gediminas Technical University, Vilnius, Lithuania
}

\begin{abstract}
Today, state enterprises and municipalities are concerned about the non-effective use of public buildings. The optimization of their quantity, efficient management by ensuring rational use of resources and protecting the societal needs are complex tasks, therefore require the decisions, which based on the application of new knowledge. The article proposes a new knowledge-based management model, an original set of criteria for assessing the efficiency of public buildings use. The task of applying this original criteria system for assessing the efficiency of the use of cultural buildings of the exact municipality has been solved. With the help of the new model, municipalities will expand the possibilities for impartial decision-making and evaluate the efficiency of end-use of buildings with respect to social benefit criteria. The results are applicable to public sector organizations, especially for municipalities with particular problems associated with the management of a large number of public assets
\end{abstract}

Keywords: sustainability, municipalities, public buildings, end-use efficiency, model, social benefit, expert systems.

\section{Introduction}

Urban development problems include certain issues depending on research object and scope of analysis: sustainable buildings' design problems, problems associated to sustainable city district developments, whole city and its' infrastructure development problems. An analysis of the research in sustainable urban development revealed that current studies usually focus on research of simple problems existent at lower hierarchical levels: selection of rational design solutions, selection of construction elements, systems and materials, the selection of contractors, etc. Research on buildings managed by public sector institutions mainly focuses on infrastructure management (Alam, et al., 2019; Bryson, et al., 2018; Giglio, Friar, \& Crittenden, 2018), facility management (Gross \& Źróbek, 2015), energy efficiency in buildings and modernization (Pardo-Bosch \& Aguado, 2016), and asset management throughout the life cycle (Ruparathna, Hewage, \& Sadiq, 2017). However, very few of major European cities are able to provide data on the amount and value of their public buildings (Yilema \& Gianoli, 2018). Information systems usually provide a detailed data on inventory of assets, a geographic map of assets, information on their use, size, value and other relevant data. Although municipalities manage the data on real estate necessary for carrying out their administrative functions, the key issue remains unsolved. This is the strategic asset management by ensuring the rational use of resources, assuring transparent services for the society. Municipal real estate portfolios need to be optimized through their rational management to ensure that they meet public interests.

The article proposes a new knowledge-based management model and an original set of criteria for assessing the use efficiency of public buildings. The proposed model and criteria set validated by case study analysis.

\section{Proposed approach and system of criteria}

An original approach was proposed for asset efficiency assessment (Figure 1). This model evaluates sustainability factors including social, economic and environmental. The attention is paid to the economic efficiency of the property use and to ensuring social needs. The model proposed the tool for the analysis of management processes of public buildings and for improving the efficiency of decision-making. In the first stage, an analysis of environmental factors was carried out. Second, expert polls and interviews identified priorities for interest groups, stimulating and limiting factors. The asset end-use efficiency assessment model was further developed and appropriate methods were selected. The efficiency of individual groups of buildings is further assessed.

\footnotetext{
${ }^{*}$ Corresponding author. E-mail: tatjana.vilutiene@vgtu.lt
} 
Šliogeriene, J.; Vilutiene, T. 2019. The evaluation model of public buildings' management efficiency with emphasis on social aspect

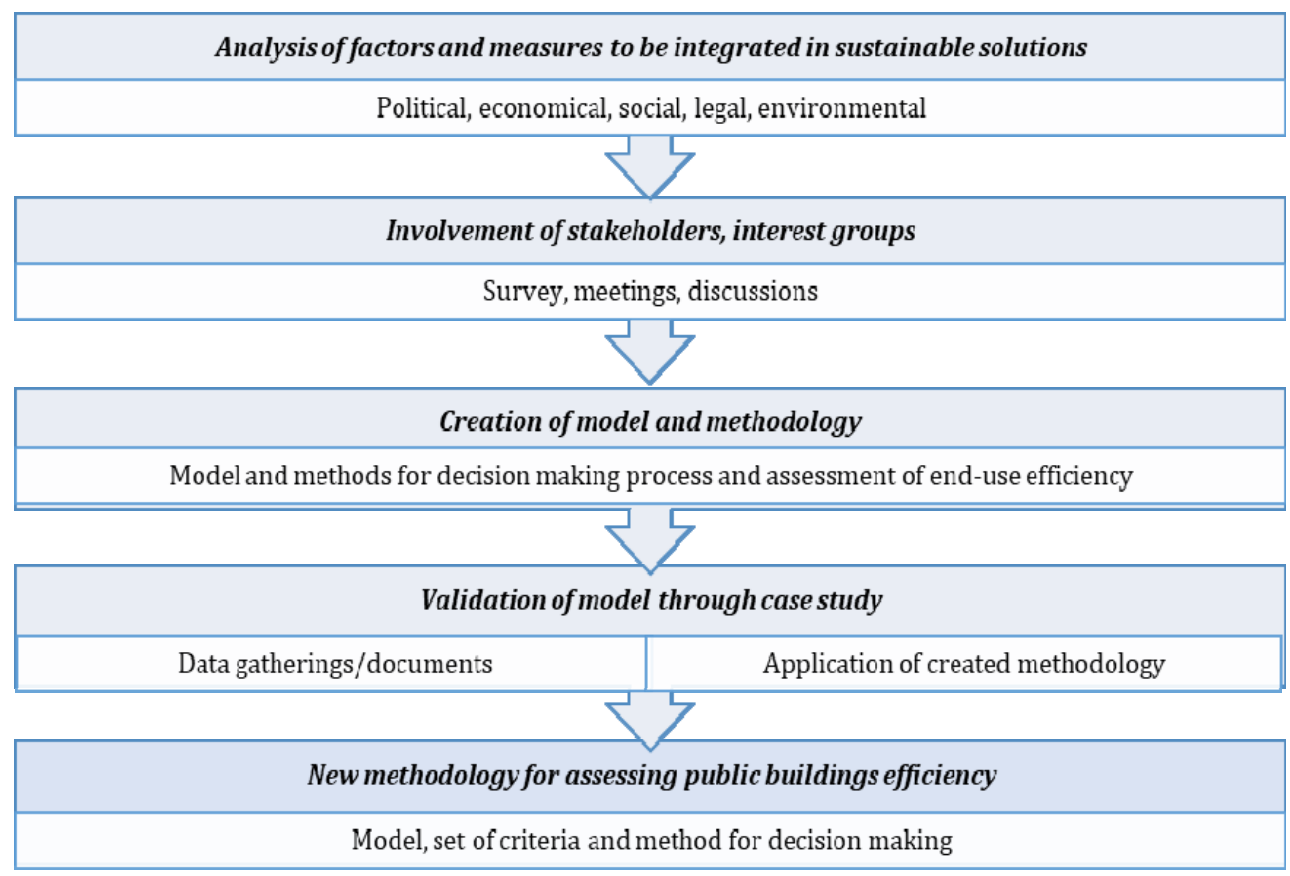

Figure 1. Proposed approach for the assessment of end-use efficiency (proposed by authors)

Assessment procedure includes following steps:

Step 1. The premises divided to the groups by type of activity.

Step 2. According to the methodology, the end-use efficiency of each premise in building $\left(R_{j, p n}\right)$ calculated, here $n$ - number of premises.

Step 3. The relative share of exact premise in the total area of the building is determined according to formula:

$$
S_{d n}=\frac{p_{n}}{D}
$$

were $p_{n}$ - the area of premise $n ; D$ - total area of building.

Step 4. The relative end-use efficiency of exact premise calculated as follows:

$$
R_{s, p n}=R_{j, p n} \times S_{d n}
$$

were $R_{j, p n}$ - the weighted sum of efficiency indicators of exact premise.

The total end-use efficiency of a building will be equal to the sum of relative efficiencies of exact premises:

$$
R_{j}=\sum_{i-1}^{n} R_{s, p n}
$$

Table 1. The set of criteria proposed for the assessment of end-use efficiency

\begin{tabular}{|c|l|c|c|}
\hline No & \multicolumn{1}{|c|}{ Criteria } & Measuring units & Significances \\
\hline I. & Strategic (political) & points & 0.2 \\
\hline 1 & Priority of activity & & 0.4 \\
\hline II. & Economical & EUR $/ \mathrm{m}^{2}$ per annum & \\
\hline 2 & Income (including rental income, sub-tenancy, incomes from investments) & EUR/ $\mathrm{m}^{2}$ per annum \\
\hline 3 & $\begin{array}{l}\text { Expenditures (including costs of management and exploitation, land taxes, } \\
\text { operating costs, investments to the modernization and expansion, losses due to } \\
\text { unused space, other expenses) }\end{array}$ & & 0.4 \\
\hline III. & Social & persons $/ \mathrm{m}^{2}$ per annum & \\
\hline 4 & Number of service users in premises & points & \\
\hline 5 & The part of tax-free services & points & \\
\hline 6 & Existence of additional social value-added services & & \\
\hline 7 & Potential social welfare losses & & \\
\hline
\end{tabular}


Step 5. The degrees of usefulness of each premise calculated as follows:

$$
N_{j, p n}=\frac{R_{s, p n}}{R_{s, p \max }} \times 100 \% .
$$

The usefulness of the whole building can only be determined if it is compared with other buildings.

The original set of criteria proposed for the assessment of buildings' end-use efficiency presented in Table 1. Experts through 3-step Delphi study determined the relative significances of criteria. Experts were required to have knowledge and experience in field of facilities management, five or more years of experience in buildings management and masters' degree or higher. Additionally, the expert panel followed the principle of "neutral" research and data collection. The weights of criteria determined taking into account the purpose of building use (building type). The relative significances for groups of criteria set by experts for cultural buildings presented in Table 1.

\section{Case study \& Results}

Buildings have a major impact on the environment, accounting for about $40 \%$ of energy consumption. It is therefore very important to use the existing building economy efficiently, using rational management techniques. State and municipal authorities responsible for facility management do not have any recommendations or methodologies for efficient management of buildings. In practice, buildings' management is limited to estimating the area per employee and the assessment of costs of buildings' utilities. The total area of premises and buildings owned by Lithuanian municipalities is approximately 11 million square meters. Lithuania has nearly four square meters per capita of municipal premises. In some municipalities, unused or inefficient use of buildings and premises is up to 30 percent.

The buildings selected for case study differ by size, construction period, expenditures, generation of revenue, and social benefits. The five buildings used for the cultural purpose selected (Figure 2).

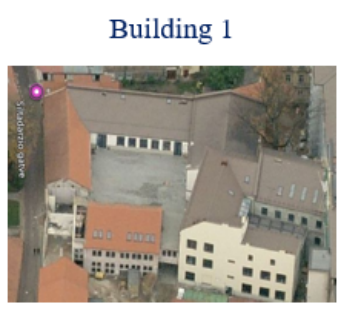

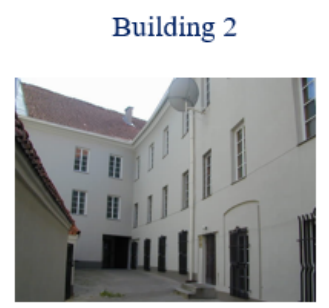

\section{Building 3}

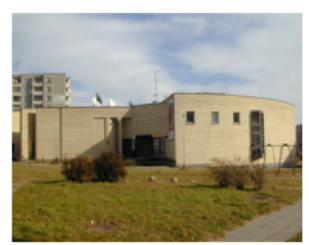

- UNESCO Heritage Area

Commercially attractive part of

town

Distance to the center of Vilnius Old Town (Town Hall) $-260 \mathrm{~m}$ The building was built between 1795 and 1860

The reconstruction was

completed in 2008

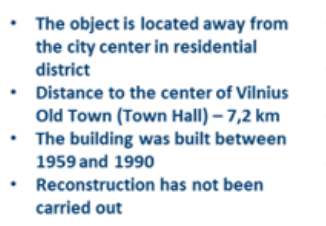

Building 4

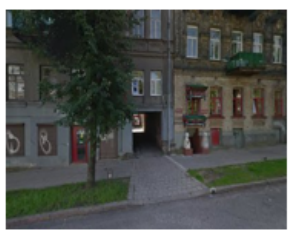

Building 5

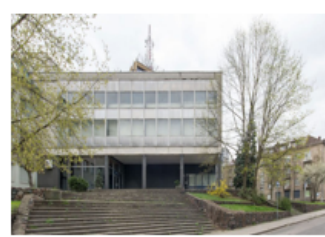

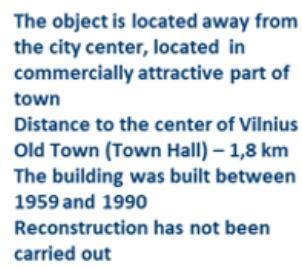

The object is located away from the city center, located in commercially attractive part of town

Distance to the center of Vilnius Old Town (Town Hall) - 1,8 km The building was built between 1959 and 1990

carried out

Figure 2. Buildings selected for the analysis and assessment of end-use efficiency

According to the results of the assessment depicted in Figure 3, the premises of building 3 used and managed more efficiently in comparison with other buildings in analyzed set.

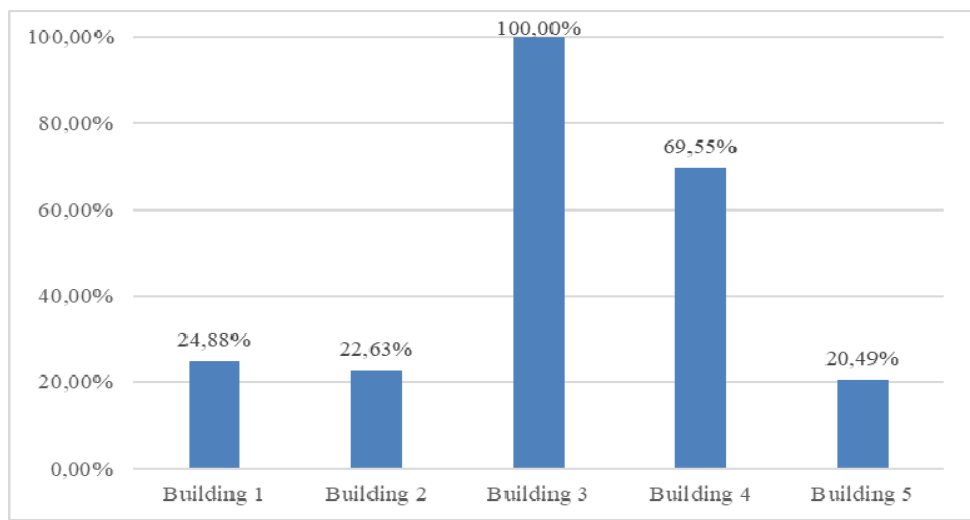

Figure 3. The results of the assessment 


\section{Conclusions}

For the defined conditions of a changing environment, a new buildings' end-use efficiency assessment model and original systems of criteria for assessing the buildings' management efficiency proposed. The criteria selected basing on sustainability approach taking into account main sustainability categories. Four criteria proposed to assess social benefits. Proposed approach is versatile and can be adapted to changing conditions by adjusting the relative significances of the criteria. A building's life cycle includes concept, design, construction, hand-over, end-use of building. Scientific research is mainly focused on design and construction, while building end-use management is almost forgotten. The research is planned to be extended by implementing an interdisciplinary research that will assess the whole system of public buildings by combining political, economic, technological, energy efficiency, environmental aspects and expected social feedback.

\section{References}

Alam, M., Zou, P. X. W., Stewart, R. A., Bertone, E., Sahin, O., Buntine, Ch., \& Marshall, C. (2019). Government championed strategies to overcome the barriers to public building energy efficiency retrofit projects. Sustainable Cities and Society, 44, 5669. https://doi.org/10.1016/j.scs.2018.09.022

Bryson, J. R., Mulhall, R. A., Song, M., Loo, B. P. Y., Dawson, R. J., \& Rogers, Ch. D. F. (2018). Alternative-substitute business models and the provision of local infrastructure: Alterity as a solution to financialization and public-sector failure. Geoforum, 95 , 25-34. https://doi.org/10.1016/j.geoforum.2018.06.022

Giglio, J. M., Friar, J. H., \& Crittenden, W. F. (2018). Integrating lifecycle asset management in the public sector. Business Horizons, 61, 511-519. https://doi.org/10.1016/j.bushor.2018.03.005

Gross, M., \& Źróbek, M. (2015). Good governence in some public real estate management systems. Land Use Policy, 49, $352-364$. https://doi.org/10.1016/j.landusepol.2015.08.017

Pardo-Bosch, F., \& Aguado, A. (2016). Sustainability as the key to prioritize investments in public infrastructures. Environmental Impact Assessment Review, 60, 40-51. https://doi.org/10.1016/j.eiar.2016.03.007

Ruparathna, R., Hewage, K., \& Sadiq, R. (2017). Developing a level of service (LOS) index for operational management of public buildings. Sustainable Cities and Society, 34, 159-173. https://doi.org/10.1016/j.scs.2017.06.015

Yilema, M. G., \& Gianoli, A. (2018). Infrastructure governance: Causes for the poor sectoral coordination among infrastructure sectors of Addis Ababa. Cities, 83, 165-172. https://doi.org/10.1016/j.cities.2018.06.019 